\title{
Rosyjski model administracji publicznej u kresu Imperium
}

\section{Uwagi ogólne}

Cesarstwo Rosyjskie aż do początku XX stulecia zachowało podstawowe cechy charakterystyczne dla feudalnej monarchii absolutnej. Ustrój państwa rosyjskiego można określić jako scentralizowaną i nieograniczoną monarchię biurokratyczną. Podobne cechy wykazywał rosyjski aparat administracyjny, który pomimo wysiłków Aleksandra I i Aleksandra II nie uległ zasadniczym zmianom przez cały wiek XIX. Na początku następnego stulecia struktura zarządu państwa rosyjskiego stanowiła już rażący anachronizm tak w porównaniu z ustrojami ówczesnych państw europejskich, jak i wobec zachodzących w Rosji na przełomie wieków przeobrażeń stosunków społecznych. Podjęte po rewolucji 1905 r. reformy były spóźnione i okazały się nietrwałe. W konsekwencji ustrój zarządu administracyjnego państwa rosyjskiego był niejednolity i często niespójny. Szczególnie wyraźnie owe cechy występowały na szczeblu centralnym, gdzie te same kompetencje wykonawcze przysługiwały kilku, pochodzącym z różnych epok, organom. W niemniejszym stopniu zróżnicowana była administracja terytorialna ${ }^{1}$.

${ }^{1} \mathrm{~W}$ literaturze rosyjskiej zagadnienia dotyczące ustroju państwa rosyjskiego $\mathrm{w}$ wieku XIX i XX poruszają m.in. następujący autorzy: A. J. Awriech, Stotypin i trietia Duma, Moskwa 1968; A. W. Czernow, Istorija gosudarstwiennych uczreżdienij Rossji do Wielikoj Oktiabrskoj Socjalisticzeskoj Rewolucji, Moskwa 1965; W. G. Czernucha, Wnutriennaja politika carizma s sierediny 50-ch do naczała 80-ch g. XIX w., Leningrad 1978; A. N. Filippow, Istorija ruskago prawa, Juriew 1906; N. P. Jeroszkin, Samodierżawie na kanunie kracha, Moskwa 1975; W. N. Łatkin, Uczebnik istorii russkago prawa perioda Imperii (XVIII-XIX wiek), Sankt Petersburg 1909; P. A. Zajonczkowskij, Prawitielstwiennyj apparat samodierżawnoj Rossji $w$ XIX $w$., Moskwa 1978. Obszerne opracowanie historii administracji rosyjskiej ze szczegółowym omówieniem wszystkich organów i dziedzin zarządu państwowego zawiera praca E. Amburgera, Geschichte der Behordenorganisation Russlands von Peter dem Grossen bis 1917, Leiden 1966. Ponadto cenne informacje o modelu działania i strukturach administra- 
$\mathrm{Z}$ istoty rosyjskiego samodzierżawia wynikało, że cała zwierzchnia władza państwowa należała do cesarza, jej wykonywanie zaś pozostawało w gestii bezpośrednio monarchy lub uprawnionych przez niego organów ${ }^{2}$. Wykluczało to możliwość formalnego podziału organów państwa na ustawodawcze i wykonawcze. W warunkach ustroju państwa rosyjskiego można było mówić jedynie o podziale funkcji na ustawodawcze i wykonawcze, przy czym podział ten zależał wyłącznie od woli cesarza-dzierżyciela pełni zwierzchniej władzy państwowej. Z tego względu prawodawstwo rosyjskie posługiwało się pojęciem „zarządu zwierzchniego" („wierchownoje uprawlenije”) lub „administracji centralnej” oraz „zarządu podporządkowanego" (,podczinnienoje uprawlenije”) lub „administracji podporządkowanej", które to pojęcia obejmowały zarówno stanowienie prawa, jak i wszystkie akty wykonawczo-administracyjne. Istota tego pierwszego polegała na bezpośrednim sprawowaniu władzy przez cesarza osobiście bądź przy udziale upoważnionych przez niego organów, takich jak Rada Państwa, Komitet Ministrów czy Senat Rządzący; drugiego - na delegowaniu określonych kompetencji monarszych do samodzielnego rozstrzygania pewnych spraw wskazanym przez niego organom, np. ministrom, gubernatorom i instytucjom samorządowym ${ }^{3}$.

cyjnych w Rosji znajdują się w opracowaniu H. Izdebskiego, Kolegialność i jednoosobowość w zarządzie centralnym państwa nowożytnego, Warszawa 1975 oraz R. Pipesa, Rosja carów, Warszawa 1990 czy tegoż, Rewolucja rosyjska, Warszawa 1994.

${ }^{2}$ Artykuł 1 Praw Zasadniczych Cesarstwa Rosyjskiego stanowił: „,Imperator Wszechrosyjski jest monarchą samodzierżawnym i nieograniczonym. Posłuszeństwo należne Jego władzy najwyższej nakazuje sam Pan Bóg, nie tylko ze względu na strach, ale także ze względu na sumienie", Swod Osnownych Gosudarstwiennych Zakonow, izdanije 1832 [dalej: Osnownyje Zakony, izdanije 1832]; Swod Zakonow Rossijskoj Imperii izdanije 1832 [dalej: Swod Zakonow, izdanije 1832], t. I, cz. I, Sankt Petersburg 1835, s. 3. Definicja rosyjskiego samodzierżawia pozostała aktualna także w ostatniej redakcji Praw Zasadniczych z 1906 r.: „Imperator Wszechrosyjski sprawuje Najwyższą Władzę Samodzierżawną. Podporządkowanie się Jego woli wynika nie tylko z groźby strachu, ale ze względu na sumienie, które nakazuje sam Bóg", Osnownyje Zakony, izdanije 1906, Swod Zakonow, izdanije 1912, t. I, cz. I, Sankt Petersburg 1912, s. 1, art. 4.

${ }^{3}$ „Władza administracyjna w całym zakresie należy wyłącznie do Monarchy. W administracji centralnej Jego władza ma charakter bezpośredni, natomiast w sprawach administracji podporządkowanej Monarcha przekazuje określone kompetencje władcze organom i funkcjonariuszom działającym w Jego imieniu i na Jego rozkaz”. „Przedmiot administracji podporządkowanej, sposób jej funkcjonowania i granice powierzonej jej władzy we wszystkich, w ustanowionych organach i instytucjach państwowych zarówno wyższych, jak i niższych im podporządkowanych, są szczegółowo określone w statutach i regulaminach tych organów i instytucji". Osnownyje Zakony, izdanije 1832, s. 31, art. 80 i 81; Osnownyje Zakony, izdanije 1892, Swod Zakonow, izdanije 1892 [dalej: Swod Zakonow, izdanije 1892], t. I, cz. I, Sankt Petersburg 1892, s. 20, art. 80 i 81. 


\section{Zarząd centralny}

Najwyższym zwierzchnikiem aparatu administracyjnego w państwie był cesarz. Do niego należała pełna i nieograniczona władza wykonawcza oraz prawo mianowania urzędników. Wszystkie organy państwowe zarówno istniejące, jak i reformowane lub tworzone od nowa, powstawały jako instytucje służebne wobec monarchy, w celu ułatwienia mu sprawowania rozległej władzy oraz merytorycznego uzasadnienia słuszności podejmowanych przez niego decyzji. Stosownie do swojego uznania cesarz mógł rezygnować z posiadanych uprawnień i delegować je $\mathrm{w}$ dowolnym zakresie na poszczególne organy czy wybranych urzędników. W ten sposób powstał w Rosji charakterystyczny dla monarchii absolutnych podział władzy wykonawczej na "rząd”, uosabiany przez monarchę $\mathrm{i}$ „,administrację", czyli podległy mu bezpośrednio aparat zarządu państwem ${ }^{4}$.

Na szczeblu centralnym współdziałały z monarchą w zarządzie administracyjnym liczne organy, których kompetencje nie zostały nigdy konsekwentnie rozgraniczone. Organem, w którym miały koncentrować się wszystkie prace projektodawcze była, powołana ukazem Aleksandra I z 1/12 stycznia 1810 r., Rada Państwa (Gosudarstwiennyj Sowiet) ${ }^{5}$. Powstała z inicjatywy Michaiła Speranskiego, jako organ doradczy i pomocniczy cesarza we wszystkich sprawach prawodawczych państwa, pozbawiony jednak jakichkolwiek samodzielnych uprawnień władczych. Jej skład osobowy, liczący bisko 90 członków, miał charakter czysto biurokratyczny. Zasiadali w niej z urzędu ministrowie i kierownicy urzędów centralnych oraz osoby wybrane przez cesarza spośród kadr urzędniczych Cesarstwa ${ }^{6}$ W 1906 r. Rada Państwa stała się, obok Dumy Państwowej, druga, wyższą izbą rosyjskiego parlamentu, a jej skład osobowy i kompetencje uległy rozszerzeniu ${ }^{7}$. W 1812 r. car Aleksander I powołał do życia Komitet

${ }^{4}$ L. Jaśkiewicz, Nowożytne samowładztwo rosyjskie i jego interpretacje. Przyczynek do dziejów absolutyzmu w Rosji, PH, 1979, t. LXX, s. 679-693; A. M. Dawidowicz, Samodierżawije w epochu impierializma, Moskwa 1975, s. 12-24; H. Izdebski, Kolegialność..., s. 100-104; P. E. Kazanskij, Włast Wsierossijskogo Imperatora, Odessa 1913, s. 41-76.

${ }^{5}$ Manifest Aleksandra I z 1/12 I 1810 r. o powołaniu Rady Państwa, Połnoje Sobranije Zakonow Rossijskoj Imperii [dalej: PSZRI] 1830, nr 24064, s. 1-15.

${ }^{6}$ Uczrierżdienije Gosudarstwiennogo Sowieta, izdanije 1832, Swod Uczrieżdienij Gosudarstwiennych, Swod Zakonow izdanije 1832, t. I, cz. I, ks. I., s. 68, art. 5; Uczrierżdienije Gosudarstwiennogo Sowieta, izdanije 1892, Swod Uczrieżdienij Gosudarstwiennych, Swod Zakonow, izdanije 1892, t. I, cz. II, ks. I, s. 1-2, art. 1-7; Uczrieżdienije Gosudarstwiennogo Sowieta, izdanije 1901, Swod Uczrieżdienij Gosudarstwiennych, Swod Zakonow, izdanije 1901, t. I, cz. II, ks. I, Sankt Petersburg 1901, s. 3-4, art. 1-8.

${ }^{7}$ Manifest Mikołaja II z 20 II/5 III 1906 r., o reorganizacji Rady Państwa, PSZRI, 1906, nr 27425, s. 154-160; ukaz z 24 IV/7 V 1906 r. organizacja Rady Państwa, PSZRI, 1906, 
Ministrów (Komitiet Ministrow) - organ doradczy, koordynujący pracę poszczególnych ministrów, pozbawiony jednak samodzielnych uprawnień władczych ${ }^{8}$ W jego skład weszli wszyscy ministrowie i kierownicy urzędów centralnych, sekretarz państwa, przewodniczący Rady Państwa oraz inne osoby mianowane przez panującego. Pracami Komitetu kierował wskazany przez monarchę minister - zwykle najstarszy wiekiem. W latach 1861-1882 Komitet Ministrów obradujący pod osobistym przewodnictwem cesarza, przyjmował nazwę Rady Ministrów (Sowiet Ministrow), ale w niczym nie zmieniało to jego kompetencji i trybu działania. W Komitecie rozpoznawane były sprawy przekraczające kompetencje pojedynczych resortów, wszystkie kwestie dotyczące zarządu administracyjnego guberni syberyjskich, kaukaskich i Królestwa Polskiego oraz sprawy wniesione pod obrady Komitetu na osobiste żądanie monarchy ${ }^{9}$. W 1905 r. Komitet Ministrów został przekształcony w Radę Ministrów - pierwszy kolegialny rząd Cesarstwa Rosyjskiego z premierem na czele ${ }^{10}$. Stanowisko prawne ministrów nie uległo jednak zmianie. Nadal byli oni mianowani i odwoływani bezpośrednio przez cesarza i tylko przed nim ponosili odpowiedzialność. Rada Ministrów nie posiadała uprawnień ustawodawczych, zastrzeżonych dla monarchy i izb parlamentarnych, zyskała natomiast prawo podejmowania uchwał w sprawie wydawania aktów wykonawczych ${ }^{11}$. Najstarszym organem centralnym rosyjskiej monarchii absolutnej był Senat Rządzący (Prawitielstwujuszczij Sienat). Utworzony w marcu 1711 r. przez Piotra I odgrywał początkowo rolę instytucji regencyjnej, zastępującej monarchę we wszystkich dziedzinach

nr 27808, s. 465-475, art. 1-124; Uczrieżdienije Gosudarstwiennogo Sowieta, izdanije 1906, Swod Uczrieżdienij Gosudarstwiennych, Swod Zakonow, izdanije 1912, t. I, cz. II, ks. I., s. 29, art. 2; S. Libicki, O wydawaniu praw i ustroju instytucji prawodawczych rosyjskich, Warszawa 1890, s. 109-120; F. Ochimowski, Prawo administracyjne, Warszawa 1919, s. 188-189; N. M. Korkunow, Russkoje gosudarstwiennoje prawo, Sankt Petersburg 1908, t. II, s. 56-96.

${ }^{8}$ Ukaz z 20 III/1 IV 1812 r. o powołaniu i organizacji Komitetu Ministrów, PSZRI, 1830, nr 25043, s. 234-236, art. 1-31.

${ }^{9}$ Uczrieżdienije Komiteta Ministrow, izdanije 1832, Swod Uczrieżdienij Gosudarstwiennych, Swod Zakonow, izdanije 1832, t. I, cz. I, ks. II, s. 99-101, art. 171-175; Uczrieżdienije Komiteta Ministrow, izdanije 1892, Swod Uczrieżdienij Gosudarstwiennych, Swod Zakonow, izdanije 1892, t. I, cz. II, ks. II, s. 1-5, art. 1-22; S. Libicki, O wydawaniu..., s. 128-146; F. Ochimowski, Prawo administracyjne..., s. 190-191; N. M. Korkunow, Russkoje..., s. 154-166.

${ }^{10}$ Ukaz z 19 X/1 XI 1905 r., o powołaniu Rady Ministrów, Sobranije Uzakonienij i Riasporiażenij Rossijskoj Imperii [dalej: SUIRP], Sankt Petersburg1905, nr 1660, s. 1.

${ }^{11}$ Uczrieżdienije Sowieta Ministrow, izdanije 1906, Swod Uczrieżdienij Gosudarstwiennych, Swod Zakonow, izdanije 1912, t. I, cz. II, ks. II, s. 102-104, art. 1-19; F. Ochimowski, Prawo administracyjne..., s. 189-191; W. M. Gribowskij, Gosudarstwiennoje ustrojstwo i uprawlenije Rossijskoj Imperii, Odessa 1912, s. 123-128. 
zarządu państwa podczas jego nieobecności w stolicy ${ }^{12}$. Z tego względu wyposażono go w szerokie kompetencje administracyjne, sądowe i nadzorcze, a także w prawo wydawania ukazów, które ogłaszane były na równi z aktami prawodawczymi cesarza. Tak szeroki zakres uprawnień Senatu uległ w czasach panowania Katarzyny II i Aleksandra I znaczącej redukcji. Ukazem z 15/26 grudnia 1763 r. Senat podzielono na odrębne i samodzielne $\mathrm{w}$ działaniu departamenty ${ }^{13}$. Od tej pory przestał on występować jako jednolite kolegium. W nowej organizacji, z 1802 r., Senat utracił niemal wszystkie dotychczasowe uprawnienia, a jego kompetencje sprowadzono głównie do funkcji sądowych ${ }^{14}$. W drugiej połowie XIX w. Senat był przede wszystkim najwyższą - od 1864 r. kasacyjną - instancją sądową w sprawach cywilnych i karnych oraz organem rozstrzygającym spory administracyjne i jurysdykcyjne. Zachował jednak dwa istotne uprawnienia w zakresie ustawodawstwa. Przysługiwało mu prawo wykładni obowiązujących aktów prawnych oraz publikacja wszystkich nowych aktów ustawodawczych ${ }^{15}$. Samodzielną pozycję wśród organów centralnych Cesarstwa Rosyjskiego zajmowała Własna J. C. M. Kancelaria, która w znacznej mierze dublowała kompetencje pozostałych władz centralnych. Szczególną rolę odegrał jej Wydział III, któremu podlegały sprawy policji i oddzielny korpus żandarmerii. Dopiero po jego likwidacji w 1880 r. Kancelaria stała się przybocznym biurem cesarza ${ }^{16}$.

Od 1802 r. naczelnymi organami administracji państwowej, na których spoczywał główny ciężar zarządzania krajem, byli ministrowie. Stali oni na czele podległych im ministerstw: Spraw Wewnętrznych, Spraw Wojskowych, Marynarki, Spraw Zagranicznych, Finansów, Oświecenia Publicznego, Sprawiedliwości, Dworu Cesarskiego, Komunikacji (od

${ }^{12}$ Ukaz z 2/13 III 1711 r. o władzy i odpowiedzialności Senatu Rządzącego, PSZRI, 1830, nr 2328, s. 634-635; ukaz z 5/16 III 1711 r. o porządku prowadzenia spraw w Senacie Rządzącym i obowiązkach oberfiskała, PSZRI, 1830, nr 2331, s. 635-636.

${ }^{13}$ Manifest Katarzyny II z 15/26 XII 1763 r. o organizacji wewnętrznej Senatu Rządzącego, PSZRI, 1830, nr 11989, s. 462-468, art. 1-9.

${ }^{14}$ Ukaz z 8/20 IX 1802 r. o prawach i obowiązkach Senatu Rządzącego, PSZRI, 1830, nr 20405, s. 241-243.

${ }^{15}$ Uczrieżdienije Prawitielstwujuszczago Sienata, izdanije 1832, Swod Uczrieżdienij Gosudarstwiennych, Swod Zakonow, izdanije 1832, t. I, cz. II, ks. III, 114-123, art. 253-298; Uczrieżdienije Prawitielstwujuszczago Sienata, izdanije 1892, Swod Uczrieżdienij Gosudarstwiennych, Swod Zakonow, izdanije 1892, t. I, cz. II, ks. IV, 1-3, art. 1-11; S. I. Pietrowskij, O Sietatie w carstwowanije Pietra Wielikago, Moskwa 1875, s. 18-36; I. J. Andrejewskij, Policejskoje prawo, Sankt Petersburg 1874, s. 236-245; A. D. Gradowskij, Wysszaja administracja w Rossiji w XVIII w., Sobranije soczinienij, t. I, Sankt Petersburg 1899, s. 228.

${ }^{16} \mathrm{~J}$. W. Oriechowskij, Trietije otdielenije, „Woprosy Istorii” 1972, № 2, s. 109-120; K. Koranyi, Powszechna historia państwa i prawa. Od rewolucji francuskiej do rewolucji październikowej, Warszawa 1962, s. 54-55. 
1865 r.), Handlu i Przemysłu (od 1905 r.) oraz Dóbr Państwowych, które w 1905 r. przekształcone zostało w Główny Zarząd Urządzeń Rolnych i Rolnictwa. Równe ministerstwom stanowisko miała Kontrola Państwowa, której zarządzającemu przysługiwała ranga ministra ${ }^{17}$. Ministrowie byli mianowani bezpośrednio przez cesarza i tylko przed nim ponosili odpowiedzialność. Powierzonymi sobie resortami kierowali jednoosobowo, a ze swej działalności składali sprawozdania bezpośrednio cesarzowi. Wchodzili w skład Rady Państwa, ale nie tworzyli gabinetu. Szczególną pozycję zajmował wśród nich minister spraw wewnętrznych. $\mathrm{W}$ jego resorcie połączono zwierzchni nadzór nad organami rządowej administracji ogólnej i samorządem oraz sprawy bezpieczeństwa i policji. Specyfiką administracji rosyjskiej było wyposażenie ministra spraw wewnętrznych w szerokie uprawnienia prawotwórcze i karno-policyjne. Miał on prawo samodzielnego wydawania rozporządzeń koniecznych wedle jego uznania - do utrzymania porządku i bezpieczeństwa publicznego. W szczególności był upoważniony do wydawania w drodze administracyjnej zakazów pobytu w pewnych częściach państwa osób zagrażających w jego mniemaniu porządkowi publicznemu oraz nakazów przymusowego osiedlenia takich osób nawet $\mathrm{w}$ guberniach syberyjskich. Mógł też zarządzić stan ochrony wzmocnionej oraz wnosić do Komitetu Ministrów wnioski o wprowadzenie stanu ochrony nadzwyczajnej na wybranym obszarze. Minister spraw wewnętrznych w Rosji kontrolował przez podległe mu organy cenzury sprawy prasowe oraz nadzorował kwestie obcych wyznań, to jest wszystkich poza prawosławnym. Tak szerokie kompetencje czyniły z niego organ charakterystyczny dla państwa policyjnego ${ }^{18}$.

\section{Zarząd lokalny}

Aparat zarządu terytorialnego był ściśle związany z podziałem administracyjnym państwa, który od reform Piotra I i Katarzyny II w XVIII stuleciu utrzymał się aż do roku 1917. Występowały w nim trzy podstawowe jednostki administracyjne: gubernia (gubernija), powiat (ujezd) oraz miasto (gorod)

${ }^{17}$ N. P. Jeroszkin, Kriepostniczeskoje samodierżawije i jego politiczeskoje instytuty, Moskwa 1981, s. 129-135; E. Amburger, Geschichte..., s. 120-138; W. M. Gribowskij, Gosudarstwiennoje..., s. 123-131.

${ }_{18}$ Ministierstwo Wnutriennych Diet, oczerk 1802-1902, Sankt Petersburg 1902, s. 132 143; E. Amburger, Geschichte..., s. 132-138; S. Grodziski, Porównawcza historia ustrojów państwowych, Kraków 1998, s. 286. 
i gmina wiejska (wołost'). Na czele guberni stali gubernatorzy (gubiernatory) i poległe im rządy gubernialne (gubiernskija prawlenija), jako bezpośredni przedstawiciele naczelnych władz administracyjnych $w$ terenie oraz organy wykonawcze ministra spraw wewnętrznych. Z niektórych guberni wewnętrznych Cesarstwa, a także z guberni położonych w prowincjach zewnętrznych, takich jak Finlandia, Kaukaz czy Królestwo Polskie tworzone były jednostki administracyjne czwartego stopnia pod nazwą generał-gubernatorstw, na czele których stali generał-gubernatorzy ${ }^{19}$. Ponadto urzędy generał-gubernatorów powołano także w stołecznym Petersburgu i w Moskwie. Gubernie dzieliły się na powiaty. Administracja powiatu spoczywała w rękach isprawnika (naczelnika) powiatu (ujezdnyj isprawnik), wybieranego przez lokalnych przedstawicieli stanu szlacheckiego. W odróżnieniu od gubernatorów i rządów gubernialnych, kompetencje isprawnika sprowadzały się przede wszystkim do funkcji policyjnych ${ }^{20}$. Oddzielne struktury organizacyjne tworzone były na potrzeby administracji specjalnej, takiej jak administracja wojskowa, skarbowa, oświatowa, pocztowa itp. ${ }^{21}$

Istotnym uzupełnieniem administracji rządowej państwa rosyjskiego stały się w drugiej połowie XIX w. instytucje samorządu terytorialnego. W 1864 r. na szczeblu guberni i powiatu utworzono samorząd ziemski. Jego organami uchwałodawczymi były gubernialne i powiatowe zgromadzenia ziemstw, wykonawczymi zaś ich zarządy z marszałkami szlachty na czele ${ }^{22}$. Samorząd ziemski pochodził z wyborów cenzusowych i kurialnych, zapewniających - zwłaszcza po 1890 r. - dominującą pozycję przedstawicielom stanu szlacheckiego. W roku 1870 powołano do życia samorząd miejski, z wybieralnymi na cztery lata dumami miejskimi jako organami uchwałodawczymi oraz zarządami miejskimi, na czele z prezydentami lub burmistrzami jako organami wykonawczymi ${ }^{23}$. Od $1861 \mathrm{r}$.

${ }^{19}$ Genezę oraz ewolucję ustrojową i kompetencyjną urzędów generał-gubernatorów i gubernatorów w Cesarstwie Rosyjskim szczegółowo omówił w swojej pracy A. Górak, Kancelaria Gubernatora i Rzad Gubernialny Lubelski (1867-1918), Lublin-Radzyń Podlaski 2006, s. 28-44.

${ }^{20}$ W. M. Gradowskij, Wysszaja administracja..., s. 141-143; N. M. Korkunow, Russkoje..., s. 331-334.

${ }^{21}$ I. A. Isajew, Istorija gosudarstwa i prawa Rossiji. Potnyj kurs lekcji, Moskwa 2002, s. 330-345; W. M. Gribowskij, Gosudarstwiennoje..., s. 131-149; E. Amburger, Geschichte..., s. $369-439$.

${ }^{22}$ Ukaz z 1/13 I 1864 r. przepisy o gubernialnych i powiatowych instytucjach ziemskich, PSZRI, 1864, nr 40457, s. 1-21, art. 1-87; L. Bazylow, Historia Rosji, Warszawa 1985, t. II, s. 303-308; J. Malec, D. Malec, Historia administracji i myśli administracyjnej, Kraków 2000, s. 132-134.

${ }^{23}$ Ukaz z 16/28 VI 1870 r. o wprowadzeniu przepisów o ustroju samorządowym miast Cesarstwa, PSZRI, 1870, nr 48498, s. 821-839, art. 1-161; L. Bazylow, Historia Rosji..., s. 313-314; J. Malec, D. Malec, Historia administracji..., s. 132-134. 
ustrój samorządowy zaczęto wprowadzać także w gminach wiejskich. Ich organami uchwałodawczymi były zgromadzenia gminne i wybierane przez nie organy wykonawcze, i sądowe, tj. zarządy gminne z wójtami i pisarzami oraz sądy gminne $z$ ławnikami ${ }^{24}$.

Cechą charakterystyczną rosyjskich reform samorządowych był ich ograniczony zasięg terytorialny, wąski zakres kompetencji własnych organów samorządowych oraz ścisła kontrola ich działalności przez organy administracji rządowej. Samorząd ziemski i miejski wprowadzono jedynie w wewnętrznych, etnicznie rosyjskich terytoriach państwa rosyjskiego (49 guberni na ogólną liczbę 78), z pominięciem guberni zamieszkałych przez mniejszości narodowe, takich jak np. gubernie Królestwa Polskiego, w których z powodów politycznych obawiano się jakiejkolwiek formy udziału lokalnej społeczności w administrowaniu sprawami publicznymi. Wyjątkiem był samorząd wiejski, który wprowadzono na całym terytorium państwa. Ze względu na niechęć czynników rządowych do zbyt daleko idącej decentralizacji administracji publicznej państwa, kompetencje własne przyznane instytucjom samorządowym ograniczono w zasadzie do kwestii drugorzędnych, takich jak zarząd sprawami: finansowymi, gospodarczymi, infrastruktura, oświatą czy opieką społeczną i służbą zdrowia. Natomiast samodzielność organów samorządowych krępował bezpośredni nadzór nad ich decyzjami sprawowany przez organy administracji rządowej, tj. przez ministra spraw wewnętrznych, gubernatorów i naczelników powiatów. Organom tym przysługiwało bezwzględne prawo uchylania decyzji organów samorządowych bez podawania uzasadnienia i możliwości odwołania. Tym niemniej, pomimo limitowania przez administrację rządową zakresu i samodzielności samorządu terytorialnego, okazał się on strukturą pożyteczną i dojrzałą politycznie, z której wywodziło się wielu działaczy okresu reform państwa rosyjskiego z początku XX w. ${ }^{25}$

${ }^{24}$ Podstawy prawne samorządu wiejskiego w Cesarstwie opierały się na takich aktach, jak Manifest Aleksandra II z 19 II/2 III 1861 r. o uwolnieniu włościan od poddaństwa, PSZRI, 1861, nr 36650, s. 128-134; oraz trzech ukazach z tej samej daty: 1. Przepisy ogólne o włościanach, PSZRI, 1861, nr 366573, s. 141-169, art. 1-207; 2. Miejscowe przepisy o organizacji włościan w guberniach wielkorosyjskich, noworosyjskich i białoruskich, PSZRI, 1861, nr 36662, s. 231-273, art. 1-269; 3. Miejscowe przepisy o organizacji włościan w guberniach małorosyjskich, PSZRI, 1861, nr 36663, s. 273-307, art. 1-258.

${ }^{25}$ L. Jaśkiewicz, Administracja carska a samorzad terytorialny w epoce Aleksandra III, KH, 1978, nr 2, s. 288-290; J. Baszkiewicz, Powszechna historia ustrojów państwowych, Gdańsk 1998, s. 318-320. 


\section{System biurokratyczny}

Aparat państwowy rosyjskiej monarchii absolutnej swoje funkcje spełniał dzięki zastosowaniu systemu biurokratycznego zarówno jako podstawy organizacji administracji, jak i zasady rekrutacji, wynagradzania i awansowania kadr urzędniczych. Jego głównymi cechami były: resortowy podział kompetencji wykonawczych wszystkich organów zarządu cywilnego państwa, wielostopniowa struktura urzędów w każdym pionie administracji, hierarchiczna zależność organów niższego stopnia od wyższych i taka sama podległość służbowa urzędników. Przede wszystkim zaś system biurokratyczny wyróżniał zawodowy charakter administracji, opierającej swą działalność na wykwalifikowanym i uposażonym przez państwo korpusie urzędników mianowanych, których stanowisko prawne zostało ujęte w osobnym statucie o służbie cywilnej ${ }^{26}$.

Podstawą funkcjonowania biurokracji rosyjskiej była zasada legalizmu, zgodnie z która, wszystkie organy państwa miały działać w ramach obowiązującego prawa. Ponieważ jednak aż do 1906 r. prawo pochodziło wyłącznie od monarchy, nie mogło być poza nim żadnego innego prawnego punktu odniesienia, na przykład konstytucji, który umożliwiałby organom państwowym utrzymanie względnej niezależności od woli cesarza. W tej postaci legalizm z natury rzeczy był raczej konstrukcją teoretyczną niż treścią praktyki życia państwowego w Rosji. Ministrowie rosyjscy nie mieli żadnej, nawet teoretycznej, możliwości uniknięcia ingerowania w sprawy należące do ich kompetencji czy to bezpośrednio przez samego cesarza, czy też za pośrednictwem jego kancelarii. Po 1864 r. monarcha rosyjski nie miał już takiej możliwości jedynie wobec wymiaru sprawiedliwości, gdzie na przeszkodzie stała formalna, ale przestrzegana w praktyce niezawisłość sądowa. Jednakże poza sądownictwem, nad całym aparatem państwowym w Rosji nadal dominował cesarz jako najwyższy i suwerenny organ państwa, którego wola była utożsamiana z racją stanu państwa ${ }^{27}$.

Brak jakichkolwiek, poza monarcha, niezależnych instytucji kontrolujących funkcjonowanie administracji rosyjskiej prowadził w konsekwencji do jej całkowitego upolitycznienia. Oznaczało to takie wprzęgnięcie całego ustroju zarządu cywilnego w system policyjnego sterowania pań-

${ }^{26}$ H. Izdebski, Historia administracji, Warszawa 1997, s. 63-64; R. Pipes, Rewolucja rosyjska..., s. 47-51; Z. Chmielewski, Narodziny i rozwój biuralizmu na ziemiach polskich w okresie zaborów, ZNUSz, 1993, nr 113, s. 26-28.

${ }^{27}$ P. E. Kazanskij, Włast..., s. 46-65; J. Malec, Historyczne modele rozwoju biurokracji, [w:] Biurokracja. Fenomen władzy politycznej w strukturach administracyjnych, red. K. Zuba, Torun 2007, s. 21. 
stwem, w którym kierunki i zakres działania administracji były dostosowywane na bieżąco do aktualnych preferencji politycznych państwa, a nie do potrzeb i oczekiwań obywateli. Zjawisku temu towarzyszyło stałe rozbudowywanie aparatu ścisłego nadzoru i kontroli nad społeczeństwem oraz charakterystyczna dla monarchii absolutnych policyjna wszechobecność państwa. Powodowało to nie tylko ograniczenie praw obywateli, ale także wynaturzenia w funkcjonowaniu machiny biurokratycznej. Nadmierne scentralizowanie aparatu biurokratycznego umożliwiało naczelnym władzom resortowym ingerowanie $w$ kompetencje władz terenowych i podejmowanie decyzji nawet w błahych kwestiach, co prowadziło do znacznych opóźnień w załatwianiu spraw, jak i częste niedostosowanie podjętych decyzji do warunków lokalnych, których urzędnicy szczebla centralnego nie byli w stanie należycie poznać2 ${ }^{2}$.

Charakterystyczną cechą organizacji i funkcjonowania biurokracji rosyjskiej była zasada jednoosobowego kierownictwa. Została ona wprowadzona $\mathrm{w}$ organach zarządu cywilnego wszystkich szczebli na początku wieku XIX i przetrwała do końca istnienia administracji cywilnej Cesarstwa. Zasada ta w warunkach państwa absolutnego stanowiła dla władz centralnych w Petersburgu dogodny środek oddziaływania na organy administracji terenowej, gdyż ułatwiała nadzór nad ich działalnością i stwarzała możliwość bezpośredniego dyscyplinowania kadr urzędniczych niższych szczebli. Przyjęcie jej w rosyjskim systemie biurokratycznym powodowało jednak nadmierną koncentrację kompetencji decyzyjnych w rękach pojedynczych urzędników - szefów poszczególnych organów zarządu cywilnego. Ministrowie, gubernatorzy i naczelnicy powiatów rozstrzygali osobiście w zasadzie o wszystkich sprawach należących do właściwości podległych im urzędów. Nawet utrzymanie kolegialnej formy działania rządów gubernialnych nie podważało zasady jednoosobowego kierownictwa w stosunku do gubernatorów, gdyż ci ostatni nie tylko przewodniczyli ich obradom, ale także mianowali ich członków i zatwierdzali wszystkie istotne ich postanowienia. $\mathrm{Z}$ formalnego punktu widzenia przyjęcie zasady jednoosobowego kierownictwa sprowadzało funkcje pozostałych pracowników urzędu do roli personelu pomocniczego - przybocznego biura naczelnika urzędu. W praktyce jednak zapewnienie sprawnego funkcjonowania całego aparatu zarządu cywilnego wymuszało konieczność przeprowadzenia w każdym urzędzie wewnętrznej dekoncentracji czynności administracyjnych, która polega-

${ }^{28}$ Z. Chmielewski, Przejawy upolitycznienia administracji polskiej w XIX i XX wieku. Zarys problemu, ZNUSz, 1992, nr 98, s. 63-74; G. Smyk, Zasady funkcjonowania rosyjskiego modelu biurokratycznego w Królestwie Polskim po powstaniu styczniowym, „Studia z Dziejów Państwa i Prawa Polskiego" 2006, t. IX, cz. 2, s. 412-414. 
ła na delegowaniu części kompetencji naczelników urzędów na podległych im urzędników. W rzeczywistości więc główny ciężar prowadzenia spraw spoczywał w każdym urzędzie na radcach, referentach i innych urzędnikach kierujących poszczególnymi wydziałami i referatami. Prawo do ostatecznej decyzji pozostawało jednak nadal w rękach szefów owych urzędów ${ }^{29}$.

Przedstawione wyżej zasady organizacji i funkcjonowania rosyjskiego modelu administracji i biurokracji zostały wprowadzone do organów zarządu cywilnego w Królestwie Polskim równocześnie z reorganizacją miejscowego aparatu administracyjnego po powstaniu styczniowym. W efekcie działań unifikacyjnych i likwidacji odrębności administracyjnej Królestwa Polskiego, w latach 1866-1876 wszystkie nowo utworzone, jak i zreformowane organy miejscowego zarządu cywilnego zostały podporządkowane właściwym resortowo władzom centralnym w Petersburgu. W ten sposób organy administracji cywilnej Królestwa stały się częścią zintegrowanego aparatu administracji terytorialnej Cesarstwa.

\section{Bibliografia}

\section{Źródła}

Połnoje Sobranije Zakonow Rossijskoj Imperii, No 24064, Sankt Petersburg 1830.

Swod Osnownych Gosudarstwiennych Zakonow, izdanije 1832, Sankt Petersburg 1832.

Swod Zakonow Rossijskoj Imperii izdanije 1832, t. I, cz. I, Sankt Petersburg 1835.

Swod Zakonow Rossijskoj Imperii, izdanije 1892, t. I, cz. I, Sankt Petersburg 1892.

Swod Zakonow Rolssijskoj Imerii, izdanije 1912, t. I, cz. I, Sankt Petersburg 1912.

\section{Opracowania}

Amburger E., Geschichte der Behordenorganisation Russlands von Peter dem Grossen bis 1917, Leiden 1966.

Andrejewskij I. J., Policejskoje prawo, Sankt Petersburg 1874.

Awariach A. J. , Stotypin i trietia Duma, Moskwa 1968.

Baszkiewicz J., Powszechna historia ustrojów państwowych, Gdańsk 1998.

Bazylow L., Historia Rosji, t. II, Warszawa 1985.

Chmielewski Z., Narodziny i rozwój biuralizmu na ziemiach polskich w okresie zaborów, ZNUSz, 1993, nr 113.

Chmielewski Z., Przejawy upolitycznienia administracji polskiej w XIX i XX wieku. Zarys problemu, ZNUSz, 1992, nr 98.

${ }^{29}$ Z. Chmielewski, Narodziny i rozwój biuralizmu na ziemiach polskich..., s. 26-28; H. Izdebski, Historia administracji..., s. 42-43; G. Smyk, Zasady funkcjonowania..., s. 410. 
Czernow A. W., Istorija gosudarstwiennych uczreżdienij Rossji do Wielikoj Oktiabrskoj Socjalisticzeskoj Rewolucji, Moskwa 1965.

Czernucha W. G., Wnutriennaja politika carizma s sierediny 50-ch do naczała 80-ch g. XIX w., Leningrad 1978.

Dawidowicz A. M., Samodierżawije w epochu impierializma, Moskwa 1975.

Filippow A. N., Istorija ruskago prawa, Juriew 1906.

Górak A., Kancelaria Gubernatora i Rząd Gubernialny Lubelski (1867-1918), LublinRadzyń Podlaski 2006.

Gradowskij A. D., Wysszaja administracja w Rossiji w XVIII w., Sobranije soczinienij, t. I, Sankt Petersburg 1899.

Gribowskij W. M., Gosudarstwiennoje ustrojstwo i uprawlenije Rossijskoj Imperii, Odessa 1912.

Grodziski S., Porównawcza historia ustrojów państwowych, Kraków 1998.

Isajew I. A., Istorija gosudarstwa i prawa Rossiji. Połnyj kurs lekcji, Moskwa 2002.

Izdebski H., Historia administracji, Warszawa 1997.

Izdebski H., Kolegialność i jednoosobowość w zarządzie centralnym państwa nowożytnego, Warszawa 1975.

Jaśkiewicz L., Administracja carska a samorząd terytorialny w epoce Aleksandra III, KH, 1978, nr 2.

Jaśkiewicz L., Nowożytne samowładztwo rosyjskie i jego interpretacje. Przyczynek do dziejów absolutyzmu w Rosji, PH, 1979, t. LXX.

Jeroszkin N. P., Kriepostniczeskoje samodierżawije i jego politiczeskoje instytuty, Moskwa 1981.

Jeroszkin N. P., Samodierżawie na kanunie kracha, Moskwa 1975.

Kazanskij P. E., Włast Wsierossijskogo Imperatora, Odessa 1913.

Koranyi K., Powszechna historia państwa i prawa. Od rewolucji francuskiej do rewolucji październikowej, Warszawa 1962.

Korkunow N. M., Russkoje gosudarstwiennoje prawo, Sankt Petersburg 1908.

Libicki S., O wydawaniu praw $i$ ustroju instytucji prawodawczych rosyjskich, Warszawa 1890.

Łatkin W. N., Uczebnik istorii russkago prawa perioda Imperii (XVIII-XIX wiek), Sankt Petersburg 1909.

Malec J., Historyczne modele rozwoju biurokracji, [w:] Biurokracja. Fenomen władzy politycznej w strukturach administracyjnych, red. K. Zuba, Torun 2007.

Malec J., Malec D., Historia administracji i myśli administracyjnej, Kraków 2000.

Ochimowski F., Prawo administracyjne, Warszawa 1919.

Oriechowskij J. W., Trietije otdielenije, „Woprosy Istorii” 1972, № 2.

Pietrowskij S. I., O Sietatie w carstwowanije Pietra Wielikago, Moskwa 1875.

Pipes R., Rewolucja rosyjska, Warszawa 1994.

Pipes R., Rosja carów, Warszawa 1990.

Smyk G., Zasady funkcjonowania rosyjskiego modelu biurokratycznego w Królestwie Polskim po powstaniu styczniowym, "Studia z Dziejów Państwa i Prawa Polskiego" 2006, t. IX, cz. 2.

Zajonczkowskij P. A., Prawitielstwiennyj apparat samodierżawnoj Rossji w XIX w., Moskwa 1978. 